Copyright (C) 2017 by Academic Publishing House Researcher

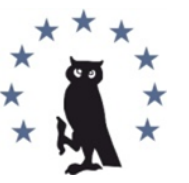

Published in the Russian Federation

European Researcher. Series A

Has been issued since 2010.

ISSN 2219-8229

E-ISSN 2224-0136

2017, 8(3): 236-244

DOI: $10.13187 /$ er.2017.3.236

www.erjournal.ru

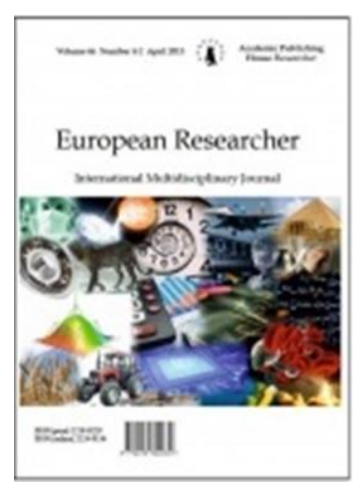

UDC 698

\title{
Analysis of Factors Affecting the Risk of Failure in Achieving the Project Targets on the Construction Activity of Samarinda Baru Airport
}

\author{
Royan Hargi Saputra ${ }^{a,{ }^{*}}$, Kustamar a , Bambang Wedyantadji a \\ a National Institute of Technology Malang, Indonesia
}

\begin{abstract}
This research aims to: 1) analyze the factors affecting the risk of failure in achieving the project targets on time and in appropriate quality on the construction activity of Samarinda Baru Airport, 2) analyze the most dominant factors affecting the risk of failure in achieving project targets on time and in appropriate quality on the new construction activity of Samarinda Airport, 3) determine the strategies used to minimize the risk of failure achieving the project targets. Reviewing the research method, this research is a descriptive research in which it is obtaining any factors affecting the risk of failure in achieving the project targets on time and in appropriate quality on the construction activity of Samarinda Baru Airport in Samarinda city and its most dominant factors. The results of the research are: 1) factors that affect the time target (Y1) are the budget (X1), material $\left(\mathrm{X}_{3}\right)$, design changes (X6) and the working environment $\left(\mathrm{X}_{7}\right)$, 2) factors affecting the quality targets (Y2) are budget (X1), material (X3), design changes (X6) working environment $\left(\mathrm{X}_{7}\right)$ and time target $\left(\mathrm{Y}_{1}\right)$. 3) the most dominant factor affecting the failure of time target (Y1) is the working environment factor $\left(\mathrm{X}_{7}\right)$ with the value of standarized coefficient of 0.216 , 4) the most dominant factor affecting failure of quality target (Y2) is the working environment factor $\left(X_{7}\right)$ with the value of standarized coefficient of 0.292.
\end{abstract}

Keywords: risk of failure, target, project, construction activity.

\section{Introduction}

The Unitary State of the Republic of Indonesia is the largest archipelagic country in the world; it has 13,670 islands stretching from west to east as far as 5,100 km and from north to south as far as $1,900 \mathrm{~km}$; its population spread over approximately 6,000 islands. The rapid development of several areas in Indonesia must be supported by the availability of transportation facilities and infrastructure, including air transportation. The role of air transportation is one of important factors in increasing national integration, economic activity and regional economic balance.

One of the efforts in supporting community activities is by improving the air transportation infrastructure to support national and regional construction which then can give a better impact and encourage people to make higher, complex and wider movement by shortening travel time to the whole area of Samarinda City.

\footnotetext{
${ }^{*}$ Corresponding author

E-mail addresses: royan.saputra1982@gmail.com (R.H. Saputra)
} 
Airport construction activities are carried out in the area of East Kalimantan Province consisting of Samarinda Baru Airport, Maratua Airport, and Datah Dawai Airport to increase the capacity of airside facilities of the airport consisting of Runway, Taxiway and Apron. The construction of airside facilities, as an area of airplane movement, is carried out to meet the requirement that is mentioned in the Regulation of the Minister of Transportation No. KP 29 of 2014 by considering the availability of budget, duration of implementation and quality of the requirements.

Construction work or physical development is a dynamic business field where many things are deemed as uncertain based on the characteristics of the project. Project characteristics that distinguish it from the operational projects are: project is unique, has duration of implementation that does not recur, has the intensity of activity and uses inconstant resources, and involves many disciplines.

Implementation of the project is declared successful if it can achieve the targets of the project which are defined as appropriate cost, quality and on time through planning, project organization, control of the available resources (Appold, Kasarda, 2006). The unique characteristic of each project requires a number of indicators to be declared successful based on the position of each party.

The work quality from the airside facilities has to be good so that the airplanes passing above it are safe and comfortable (Cruz, Marques, 2011). However, in reality, many quality results of Runway work are found inappropriate according to the requirements, so that damages happen before its time to happen, and also during the work implementation process (including the maintenance period) are often found inappropriate quality so that it must be disassembled and reworked.

Rework causes the failure of project work time. The impact of rework affects on the irregularities of plan achievement progress of the work depending on the type of work and volume of the work, the impact of rework will causes the unplanned time costs (Kasarda, 2006). The costs are not only direct costs but rework affects on the incidence of indirect costs; the impact of indirect costs even can be greater than the direct cost of rework. The impact of indirect costs may include overhead costs, administrative costs, motivation and morale of the labors and others (Yang et al, 2014).

According to planning, the type of pavement used in Runway and Taxiway of Samarinda Baru Airport is a type of flexible pavement using hotmix asphalt as the top layer. In its implementation, some improvements and demolition works are made, or in other words, rework is the illustration of the inappropriate work of the quality performance of the project.

Risks during the implementation phase of flexible pavement type, which may result in failure of the product quality, so that it should be dismantled and reworked, are caused by several factors, including aspects of human resources, material aspects and managerial aspects during the implementation phase, for example the planning and scheduling of the project is not perfect, poor data/information distribution, slow decision making and lack of clarity of coordination between parties. Other risks for product quality failures are field conditions such as poor weather, difficult field conditions, frequent social problems in the field, wrong implementations, equipment limitations, unequal equipment, equipment selection and inappropriate work methods. In addition, the design and documentation aspects are also risk factor for inappropriate quality, such as unclear specifications, unclear work drawings, and not integrated documentation system in the field.

Risk identification is required to view and review the risk factors that are going to be faced and review the impact on the project targets so that the treatment strategies will be known to minimize the bad impacts so that it support the achievement of the project targets on time and in appropriate quality (Terwiesch et al, 2002). Risk identification is an important step in project implementation. Through the risk identification in the construction project implementation process, it will be known the risks that can occur during the implementation of the project since the project began to work until the project is handed over. Moreover, the potential of these risks will be known in affecting the failure of achievement of the project targets on time and in appropriate quality.

Characteristics of Runway and Taxiway's flexible pavement work on New Samarinda Airport Development Activities are intensive tool, intensive labor, heavily influenced by weather, difficult job terrain, and frequent social problems. Identification of risk can be started from these characteristics to obtain a risk management plan so that the planned quality targets can be achieved without experiencing rework on the product of the work implementation results (LopezLorca et al, 2011). 
Identifying risks earlier through well-conducted analyzes is expected to support the probability improvement of achieving project targets on time and in appropriate quality. In accordance with the background mentioned above, it is necessary to analyze and identify the factors affecting the risk of failure in achieving the project targets on time and in appropriate quality on the construction activity of Samarinda Baru Airport. Further research results can be used for related parties in analyzing the risks and taking concrete steps in handling these risks appropriately.

From the explanations above, this study aims to: 1 ) analyze the factors affecting the risk of failure in achieving the project targets on time and in appropriate quality on the construction activity of Samarinda Baru Airport, 2) analyze the most dominant factors affecting the risk of failure in achieving project targets on time and in appropriate quality on the new construction activity of Samarinda Airport, 3) determine the strategies used to minimize the risk of failure achieving the project targets.

\section{Research Method}

Reviewing the research method, this research is a descriptive research in which it is obtaining any factors affecting the risk of failure in achieving the project targets (Sugiyono, 2015). Method of data collection in this research uses questionnaire method. The final aim of this research is to determine factors affecting the risk of failure in achieving the project targets on the construction activity of Samarinda Baru Airport in Samarinda City which is followed by determining the variables to be used as items of questions which will be measured in the form of questionnaires and strategies that must be carried out to overcome them.

This research uses survey method by collecting opinion, experience and attitude of the respondents by taking primary data from questionnaires and secondary data from the related institutions. Based on the factors affecting the risk of failure in achieving the project objectives on time and in appropriate quality on the construction activities of Samarinda Baru Airport, factors affecting the risk of failure in achieving the project objectives on time and in appropriate quality will be determined, then it is followed by determining indicators that are going to be used as the items of question which will be measured in the form of questionnaires

\section{Results And Discussion 3.1 Factor Analysis}

A set of feasible variables are to use factor analysis if it has a high level of dependency. The indication of this dependency level is determined by the value of KMO (Keizer Meyer Olkin) and MSA (Measures Sampling Adequacy). Here are the results of the selection of Time Target and Quality Target on the construction project of Samarinda Baru Airport. Selection is conducted on the value of MSA. Variable with the lowest item value of MSA and less than 0.50 will be dropped and then recount is conducted until all of the items have a value of more than 0.50 MSA. Analysis result of the 7 variables mentions that no items are dropped because all items have an MSA value of more than 0.50. After the process of selecting the feasible items; filtering the items, some items are obtained which then are eligible for analysis. Next is summarizing or extraction of the existing set of items so that they form one or more factors that are the main data structure of the construction Time Target and Quality Target (Bosi, 2015). The results of factor extraction are followed by an interpretation of the loading factor of each item (Gil et al, 2008). Factors will represent a number of items if the consideration of loading factor is more than 0.50. Loading factor also explains how big the correlation of an item with the factor. The result of loading factor used is obtained from the component matrix. If there are many significant factors, it is often difficult in the interpretation of the factors because of an overlap between the extracted factors. To overcome this problem, factor rotation is conducted. The factor extraction results will be seen from the calculation of loading factor after it is rotated (rotated component matrix). Varimax rotation method is used to obtain the optimum loading factor.

From the result of extraction factor which is followed by the interpretation of the Loading Factor of each item above, it appears that the latent variables of Budget (X1), Human Resources (X2), Materials (X3), Equipment (X4), Methods of Work Implementation ( $\mathrm{X}_{5}$ ), Design Changes (X6) and Work Environment $\left(\mathrm{X}_{7}\right)$ can be formed by grouping the manifest variables, as follows: 
1. Budget Variable (X1), is formed by manifest variables consisting of: payments by the contractor to the labors (X1.1), late payment by the contractor to the supplier (X.2), late payment by the owner to the contractor (X1.3), contractor's financial ability (X1.4), and use of contract down-payment (X1.5).

2. Human Resources Variable (X2), is formed by manifest variables consisting of: the availability of human resources (X2.1), the human resources cannot coordinate well (X2.2), the human resources does not have a great responsibility (X2.3), the human resources do not have good skills (X2.4), the attitude of the estimator is less experienced (X2.5), and the human resource is lack of productivity (X2.6).

3. Material Variable $\left(\mathrm{X}_{3}\right)$, is formed by manifest variables consisting of: a shortage of material (X3.1), the occurrence of damage and material changes (X3.2), the late procurement of the materials (X3.3), the scarcity of material (X3.4), waiting for the test result by the owner (X3.5), the absence of material test in the laboratory $\left(\mathrm{X}_{3} .6\right)$, and the deviation of material use from the specification $\left(\mathrm{X}_{3} \cdot 7\right)$.

4. Equipment Variable ( $\mathrm{X}_{4}$ ), is formed by manifest variables consisting of: inadequate operator skills (X4.1), the limited amount of equipment (X4.2), the ability of the tool is not appropriate to serve the volume of work $\left(\mathrm{X}_{4} \cdot 3\right)$, the late delivery of equipment $\left(\mathrm{X}_{4} .4\right)$, and the existing equipment are often damaged (X4.5).

5. Work Implementation Method Variable ( $\mathrm{X}_{5}$ ), is formed by manifest variables consisting of: the work does not comply with the order and stages of work that have been determined (X5.1), the implementation does not run according to predetermined specifications ( $\mathrm{X}_{5.2}$ ), and all works are not conducted well and correctly based on the provision (X5.3).

6. Design Changes Variable (X6), is formed by manifest variables consisting of: Frequent design changes by the owner due to the changed use or function from the first planning when the work is being carried out (X6.1), occurrence of delay in the process of planning changes in current implementation (X6.2), and the non-fulfillment of the first planning which has been designed by the owner, so that it causes result changes which are carried out by the contractors (X6.3).

7. Work Environment Variable $\left(\mathrm{X}_{7}\right)$, is formed by manifest variables consisting of: the condition of temporary labors and the access of the roads which are all poorly built (X7.1), the surrounnding conditions cause material damage in the storage place $\left(\mathrm{X}_{7.2}\right)$, the air temperature is hot or too cold which is disruptive to the work $\left(\mathrm{X}_{7.3}\right)$, the influence of culture at the time of the customary ceremonial which is temporarily suspend all activities in the project implementation work ( $\mathrm{X}_{7.4}$ ), frequent rains during the implementation of the work, thus impeding the work $\left(\mathrm{X}_{7.5}\right)$, the condition of work area elevation is lower than the surrounding environment $\left(\mathrm{X}_{7} .6\right)$, the maintenance of the work does not run well by the contractor $\left(\mathrm{X}_{7.7}\right)$, and there is a security disturbance and demo of citizens who disagree with the existence of the airport ( $\mathrm{X}_{7.8}$ ).

\section{targets}

3.2 Strategy as an effort to minimize the risk of failure in achieving project

Based on the result of path analysis, it is found that the independent variables that have significant value (have significant effect on the risk of failure in achieving the project targets in the construction activity of Samarinda Baru Airport) are Budget (X1), Materials (X3), Design Changes (X6) and Work Environment $\left(\mathrm{X}_{7}\right)$. While the variables that have no significant value (influential but not significant to the risk of failure in achieving project targets in the construction activities of Samarinda Baru Airport) are Human Resources (X2), Equipment (X4) and Method of Work Implementation ( $\mathrm{X}_{5}$ ). Furthermore, factors that significantly affect the risk of failure in achieving project targets in the construction activities of Samarinda Baru Airport can be explained as follows:

1. Budget Variable (X1), is formed by manifest variables consisting of: payments by the contractor to labors (X1.1), late payment by the contractor to the supplier (X.2), late payment by the owner to the contractor (X1.3), contractor's budget ability (X1.4), and use of contract downpayment (X1.5).

2. Material Variable $\left(\mathrm{X}_{3}\right)$, is formed by manifest variables consisting of: a shortage of material (X3.1), the occurrence of damage and material changes (X3.2), late procurement of the materials ( $\left.\mathrm{X}_{3} .3\right)$, the scarcity of material $\left(\mathrm{X}_{3} .4\right)$, pending test result by owner $\left(\mathrm{X}_{3} .5\right)$, the absence of material test in the laboratory ( $\left.\mathrm{X}_{3} .6\right)$, and deviation of material use from the specification $\left(\mathrm{X}_{3} .7\right)$. 
3. Variable Change Design (X6), is formed by manifest variables consisting of: Frequent design changes by the owner due to the changed use or function from the first planning when the work is being carried out (X6.1), occurrence of delay in the process of planning changes in current implementation (X6.2), and the non-fulfillment of the first planning which has been designed by the owner, so that it causes result changes which are carried out by the contractors (X6.3).

4. Work Environment Variable $\left(\mathrm{X}_{7}\right)$, is formed by manifest variables consisting of: the condition of temporary labors and the access of the roads which are all poorly built ( $\left.\mathrm{X}_{7.1}\right)$, the surrounnding conditions cause material damage in the storage place $\left(\mathrm{X}_{7.2}\right)$, the air temperature is hot or too cold which is disruptive to the work $\left(\mathrm{X}_{7.3}\right)$, the influence of culture at the time of the customary ceremonial which is temporarily suspend all activities in the project implementation work (X7.4), frequent rains during the implementation of the work, thus impeding the work (X7.5), the condition of work area elevation is lower than the surrounding environment $\left(\mathrm{X}_{7.6}\right)$, the maintenance of the work does not run well by the contractor $\left(\mathrm{X}_{7.7}\right)$, and there is a security disturbance and demo of citizens who disagree with the existence of the airport (X7.8).

Furthermore, it will discuss the strategy used to the factors that significantly affect the risk of failure in achieving project targets on the construction activities of Samarinda Baru Airport.

\subsection{Strategy Analysis Used In Budget Factors (X1)}

Based on the table, budget factor (X1) is one of the variables that affect the risk of failure in achieving the project targets on the construction activities of Samarinda Baru Airport. Positive standardized coefficient values indicate that if the budget factor (X1) is better, it can be said that most likely occur the accurate analysis of the risk of failure in achieving project targets on the construction activities of Samarinda Baru Airport. Then, to know where the most influential indicator is, whether directly or indirectly against the risk of failure in achieving project targets on the construction activities of Samarinda Baru Airport on budget factor (X1) can be seen at the highest Loading Factor in the following table:

Table 1. Values of Loading Factor on Budget Factor (X1)

\begin{tabular}{|c|c|c|}
\hline $\begin{array}{c}\text { Manifest } \\
\text { Variable }\end{array}$ & Description & Loading Value \\
\hline X1.1 & Payments by the contractor to the labors & 0.795 \\
\hline X1.5 & Use of contract down-payment & 0.793 \\
\hline X1.2 & Late payments by the contractor to the supplier & 0.783 \\
\hline X1.3 & Late payment by the owner to the contractor & 0.739 \\
\hline X1.4 & Contractor's budget ability & 0.731 \\
\hline
\end{tabular}

From the table above, it is known that the payment indicator by the contractor to the labors (X1.1) with the loading value of 0.795 is the most influencing indicator of the risk of failure in achieving project targets on the construction activities of Samarinda Baru Airport, the strategy used to overcome that is the contractor must be able to manage the budget well, one of them by creating a cash flow schedule by prioritizing the payment of salary for the labors to be done on time regularly.

\subsection{Strategy Analysis Used for Material Factors (X3)}

Other factor that directly or indirectly affects the risk of failure in achieving project targets on the construction activities of Samarinda Baru Airport is the Material Factor ( $\mathrm{X}_{3}$ ). The sequence of indicators that most influence the risk of failure in achieving project targets on the construction activities of Samarinda Baru Airport for Material Factor $\left(\mathrm{X}_{3}\right)$ can be seen in the following table: 
Table 2. Value of Loading Factor in Material Factor (X3)

\begin{tabular}{|c|c|c|}
\hline $\begin{array}{c}\text { Manifest } \\
\text { Variable }\end{array}$ & Description & $\begin{array}{c}\text { Loading } \\
\text { Value }\end{array}$ \\
\hline $\mathrm{X}_{3.1}$ & Shortage of material & 0.925 \\
\hline $\mathrm{X}_{3.3}$ & Late procurement of the material & 0.895 \\
\hline $\mathrm{X}_{3.4}$ & Material scarcity & 0.882 \\
\hline $\mathrm{X}_{3.2}$ & The occurrence of damage and material changes & 0.857 \\
\hline $\mathrm{X}_{3.5}$ & Waiting for the test results by the owner & 0.766 \\
\hline $\mathrm{X}_{3.7}$ & Deviation of material from the specification & 0.738 \\
\hline $\mathrm{X}_{3} .6$ & Absence of material test in the laboratory & 0.712 \\
\hline
\end{tabular}

Source: SPSS Analysis, 2017 (Appendix 6)

From the table above it is known that the indicators of Factor Material (X3), which most affect the risk of failure in achieving project targets on the construction activities of Samarinda Baru Airport is a shortage of material (X3.1) with a loading value of 0.925, then the strategies used to overcome them is the contractor should consider the amount of material required for each work item and anticipate the potential for loss and/or damage during the mobilization process. For the procurement of natural materials such as soil embankment, sand blanket, sand tide, aggregate, mountain stone and others, it needs to be added factor of the development of materials by $\pm 20 \%$ of the required amount based on the measured data, whereas for manufacturers material such as prefabricated vertical drains (PVD), geotextile, cement, bulk asphalt, concrete iron and other materials need to be agreed together about the model of packing and seal if necessary.

\subsection{Strategy Analysis Used For Design Changes Factor (X6)}

Design Changes Factor (X6) includes variables directly or indirectly affecting the risk of failure in achieving project targets on the construction activities of Samarinda Baru Airport. The sequence of indicators that most influence the risk of failure in achieving project targets on the construction activities of Samarinda Baru Airport for Design Changes Factor ( $\left.\mathrm{X}_{3}\right)$ can be seen in the following table:

Table 3. Values of Loading Factor on Design Changes Factor (X6)

\begin{tabular}{|c|l|c|}
\hline $\begin{array}{c}\text { Manifest } \\
\text { Variable }\end{array}$ & \multicolumn{1}{c|}{ Description } & Loading Value \\
\hline X6.2 & $\begin{array}{l}\text { The occurrence of delay on change process from planning } \\
\text { at the time of the implementation }\end{array}$ & 0.872 \\
\hline X6.3 & $\begin{array}{l}\text { Unfulfilled the first planning that has been designed by } \\
\text { the owner, resulting in changes to the results undertaken } \\
\text { by the contractor }\end{array}$ & 0.870 \\
\hline X6.1 & $\begin{array}{l}\text { Frequent changes to the design by the owner due to the } \\
\text { use or function that change from the first planning at the } \\
\text { time the work is being carried out }\end{array}$ & 0.852 \\
\hline
\end{tabular}

Source: SPSS Analysis, 2017 (Appendix 6)

From Table 4 it is known that indicators of Design Changes Factor (X6) that most affect the risk of failure in achieving project targets on the construction activities of Samarinda Baru Airport is the occurrence of delay on change process from planning at the time of the implementation (X6.2) with a loading value of 0.872 , then the strategy used to overcome it is the Working Director through the Construction Management Consultant (MK) together with the contractor should review it quickly and appropriately so that the recommendations given to the Project Leader can be immediately decided. Basically the technical justification issued by the Consultant of the Constitutional Court shall be conducted through holistic assessment by considering the aspects of cost, quality and time and by considering the laws and regulations that are applicable in the field of construction services. 


\subsection{Strategy Analysis Used In Work Environment Factor $\left(\mathrm{X}_{7}\right)$}

The Work Environment Factor $\left(\mathrm{X}_{7}\right)$ is also a variable that directly or indirectly influences the risk of failure in achieving project targets on the construction activities of Samarinda Baru Airport. The sequence of indicators that most influence the risk of failure in achieving project targets on the construction activities of Samarinda Baru Airport for Work Environment Factor (X7) can be seen in the following table:

Table 4. Values of Loading Factor on Work Environment Factor $\left(\mathrm{X}_{7}\right)$

\begin{tabular}{|c|l|c|}
\hline $\begin{array}{c}\text { Manifest } \\
\text { Variable }\end{array}$ & \multicolumn{1}{|c|}{ Description } & Loading Value \\
\hline $\mathrm{X}_{7.6}$ & $\begin{array}{l}\text { The condition of the work area elevation is lower than the } \\
\text { surrounding environment }\end{array}$ & 0.848 \\
\hline $\mathrm{X}_{7.4}$ & $\begin{array}{l}\text { The existance of culture at the time of the customary } \\
\text { ceremonial which is temporarily suspend all activities in the } \\
\text { project implementation work }\end{array}$ & 0.844 \\
\hline $\mathrm{X}_{7.5}$ & Often rains during the implementation of the work & 0.829 \\
\hline $\mathrm{X}_{7.3}$ & $\begin{array}{l}\text { Hot or too cold temperatures that interfere with the } \\
\text { implementation of work }\end{array}$ & 0.797 \\
\hline $\mathrm{X}_{7.1}$ & $\begin{array}{l}\text { The condition of temporary labors and the access of the } \\
\text { roads which are all poorly built }\end{array}$ & 0.796 \\
\hline $\mathrm{X}_{7.7}$ & $\begin{array}{l}\text { Maintenance of the work does not run well by the } \\
\text { contractor }\end{array}$ & 0.733 \\
\hline $\mathrm{X}_{7.2}$ & $\begin{array}{l}\text { The surrounding conditions cause damage to storage } \\
\text { materials in the implementation of work }\end{array}$ & 0.718 \\
\hline $\mathrm{X}_{7.8}$ & $\begin{array}{l}\text { There is a security disturbance and demo of citizens who do } \\
\text { not agree with the existence of the Airport }\end{array}$ & 0.555 \\
\hline
\end{tabular}

From the table it was found that indicators of Work Environment Factors ( 7 7), which most affect the risk of failure in achieving project targets on the construction activities of Samarinda Baru Airport is the condition of the work area elevation is lower than the surrounding environment $\left(\mathrm{X}_{7.6}\right)$ with a loading value of 0.848 , then the strategy used to overcome this is the contractor must anticipate the potential occurrence of inundation of each rainfall given the high rainfall in the area of Samarinda City by making the temporary channels in every particular distance according to the needs based on the work area (segment) that is being handled.

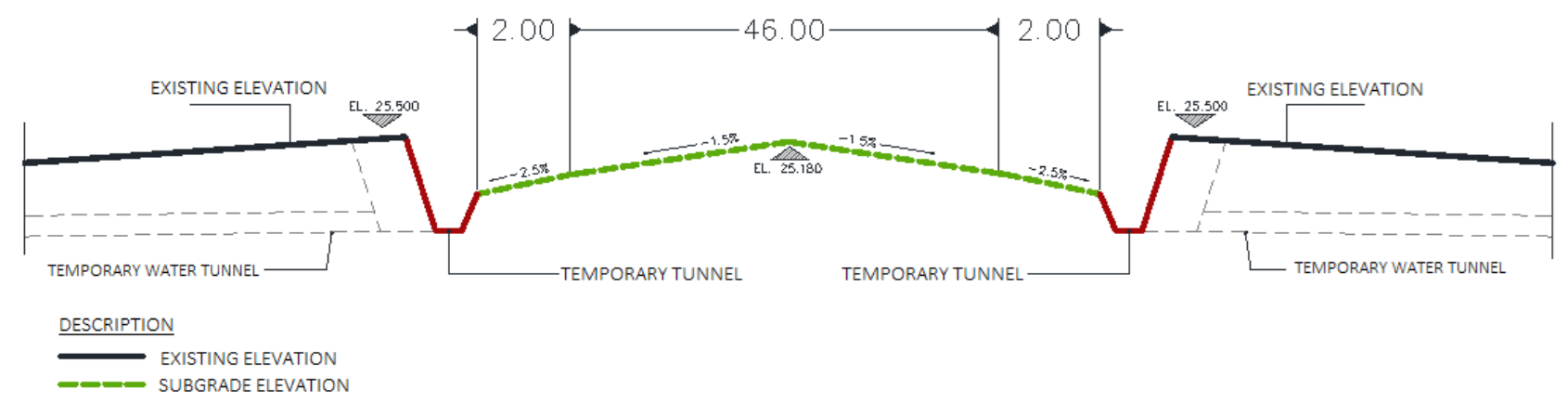

Fig. 1. Handling Sketch

The Work Director and the Construction Management Consultant (MK) should provide advice and/or instructions to the Contractor to ensure that the intended temporary channel is maintained during the work period and must be closed immediately when the pavement construction work in the area has been completed. 


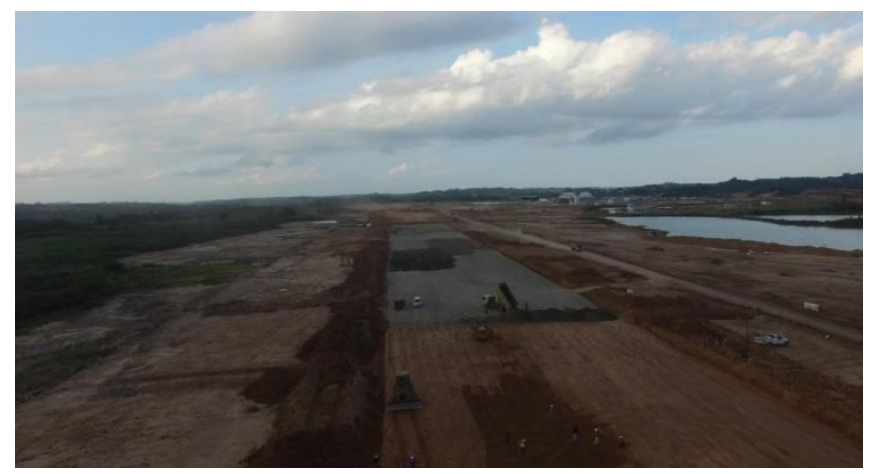

Fig. 2. Documentation of Field Implementation

\section{Conclusion}

Based on the results of research and discussion that have been described in the previous chapter, it can be concluded as follows:

1. Factors that affect the risk of failure in achieving project targets on the construction activities of Samarinda Baru Airport are as follows:

a. $\quad$ Factors affecting Time Target (Y1) are Budget (X1), Material (X3), Design Changes (X6) and Work Environment $\left(\mathrm{X}_{7}\right)$.

b. $\quad$ Factors affecting Target Quality (Y2) are Budget (X1), Material (X3), Design Changes (X6), Work Environment and and Time Target (Y1).

2. The most dominant factor affects the risk of failure in achieving project targets on time and in appropriate quality on the construction activities of Samarinda Baru Airport are as follows:

a. The most dominant factor affecting the failure in reaching Target Time (Y1) is Work Environment Factor $\left(\mathrm{X}_{7}\right)$ with value of Standarized Coefficient of 0,216.

b. The most dominant factor affecting the failure in reaching Quality Target (Y2) is Working Environment Factor (X7) with a value of Standarized Coefficient of 0.292.

3. Strategies to anticipate the risk of failure in achieving project targets on the construction activities of Samarinda Baru Airport are as follows:

a. The contractor must be able to manage budget well one of them by creating a cash flow schedule by prioritizing the payment of labors' salary to be conducted on time regularly.

b. The contractor must consider the amount of material required for each work item and anticipate the potential for loss and/or damage during the mobilization process.

c. The work director through the Construction Management Consultant (MK) together with the contractor shall review promptly and appropriately so that the recommendations given to the Project Leaders may be immediately decided.

d. The contractor should avoid the occurrence of inundation of each rainfall given the high rainfall by creating temporary channels at any particular distance according to need based on the work area (segment) that is being handled.

\section{Suggestion}

Based on the results of the analysis, then the researcher suggest to the parties to pay more attention to things below:

1. Make a plan of cash flow by prioritizing the payment of salary to be realized according to the time of the agreement on a regular basis.

2. Consider the amount of material required for each work item by adding a loss factor of at least $20 \%$.

3. The Project Leader instructs the Construction Management Consultant (MK) to review quickly and appropriately any proposed necessary design changes.

4. Create temporary channels of any particular distance according to need based on the work area (segment) that is being handled and maintain the temporary channel during the implementation period and immediately close it after construction is done. 
5. It is expected that in future research to add a few other variables such as the interpretation of planning documents and technical specifications that often lead to a dispute at the time of the implementation of work.

\section{References}

Appold, Kasarda, 2006 - Appold, S. J., Kasarda, J. D. (2006). The appropriate scale of US airport retail activities. Journal of Air Transport Management, 12(6), 277-287.

Bosi, 2015 - Bosi, F. (2015). Airport Lean Design. Looking to methods and tools for the Research in Design and Architectural Technology, 137.

Cruz, Marques, 2011 - Cruz, C. O., Marques, R. C. (2011). Contribution to the study of PPP arrangements in airport development, management and operation. Transport Policy, 18(2), 392-400.

Gil et al., 2008 - Gil, N., Beckman, S., Tommelein, I. D. (2008). Upstream problem solving under uncertainty and ambiguity: Evidence from airport expansion projects. IEEE Transactions on Engineering Management, 55(3), 508-522.

Kasarda, 2006 - Kasarda, J. D. (2006). Airport cities and the aerotropolis. Im Internet unter. URL: http://www. aerotropolis. com/files/2006_07_Airport-Cities. pdf [Access date: 12.05. 2007].

Lopez-Lorca et al., 2011 - Lopez-Lorca, A. A., Beydoun, G., Sterling, L., Miller, T. (2011). Ontology-mediated validation of software models. In Information Systems Development (pp. 455467). Springer, New York, NY. Bandung.

Sugiyono, 2015 - Sugiyono, 2015, Statistika Untuk Penelitian. Cetakan ke-26. Alfabeta.

Terwiesch et al., 2002 - Terwiesch, C., Loch, C. H., \& Meyer, A. D. (2002). Exchanging preliminary information in concurrent engineering: Alternative coordination strategies. Organization Science, 13(4), 402-419.

Yang et al., 2014 - Yang, Q., Lu, T., Yao, T., Zhang, B. (2014). The impact of uncertainty and ambiguity related to iteration and overlapping on schedule of product development projects. International Journal of Project Management, 32(5), 827-837. 